\title{
ACTION OF SELECTIVE SEROTONIN REUPTAKE INHIBITOR ON AGGRESSIVE BEHAVIOR IN ADULT RAT SUBMITTED TO THE NEONATAL MALNUTRITION
}

\author{
Jairza Maria Barreto Medeiros', Cristiano Mendes da Silva², Everton Botelho Sougey², \\ José Audisio Costa4, Célia Maria M. Barbosa de Castro ${ }^{5}$, Raul Manhães de Castro ${ }^{6}$
}

\begin{abstract}
The effect of the malnutrition during suckling on the aggressiveness was investigated in adult rats treated or not with citalopram, a selective serotonin reuptake inhibitor (SSRI). The animals were divided into two groups according to the diet used: nourished group- the rats received the control diet with $23 \%$ protein during the life; and malnourished group- the rats had its mothers submitted to diet with $7.8 \%$ protein during suckling. At 120 days of age, each group was sub-divided according to the treatment: acute - consisting a single i.p. injection of saline solution or $20-\mathrm{mg} / \mathrm{Kg}$ citalopram; chronic - consisting the single injections ( 1 per day during 14 days) of saline or $20 \mathrm{mg} / \mathrm{Kg}$ citalopram. The acute or chronic treatment with SSRI reduces aggressive response in nourished rats, but not in malnourished ones. Thus, the malnutrition during the critical period of brain development seems to induce durable alterations in the function of the serotoninergic neurotransmission
\end{abstract}

KEY WORDS: aggressive behavior, malnutrition, serotonin.

\begin{abstract}
Ação de inibidor seletivo da recaptação de serotonina sobre comportamento agressivo em rato adulto submetido à desnutrição neonatal

RESUMO - O efeito da desnutrição durante a lactação sobre a agressividade foi investigado em ratos adultos tratados ou não com citalopram, um inibidor seletivo da recaptação de serotonina (ISRS). Os animais foram divididos em dois grupos de acordo com a dieta: grupo nutrido- ratos que receberam toda a vida dieta controle ( $23 \%$ de proteína); e grupo desnutrido- ratos que tiveram suas mães submetidas a dieta com 7,8\% de proteína na lactação. Aos 120 dias de idade, cada grupo foi sub-dividido conforme o tratamento: agudo consistindo de injeção única i.p. de solução salina ou $20 \mathrm{mg} / \mathrm{Kg}$ de citalopram; crônico - consistindo de injeções únicas (1 por dia durante 14 dias) de salina ou $20 \mathrm{mg} / \mathrm{Kg}$ de citalopram. 0 tratamento agudo ou crônico com ISRS reduziu a resposta agressiva nos ratos nutridos, mas não nos desnutridos. Assim, a desnutrição durante o período crítico de desenvolvimento do cérebro parece acarretar alterações duradouras na função da neurotransmissão serotoninérgica.
\end{abstract}

PALAVRAS-CHAVE: comportamento agressivo, desnutrição, serotonina.

The role of serotonin in the control of the aggressive behavior has been demonstrated through the use of pharmacological instruments ${ }^{1}$. There are drugs that act through the selective serotonin (5-HT) reuptake inhibition; these substances increase the availability of $5-\mathrm{HT}$ in the synapse and, consequently, the action of this monoamine ${ }^{2}$. Among these substances are the citalopram, one of the most selective serotonin reuptake inhibitors (SSRI) ${ }^{3}$. The growth of the central nervous system (CNS) and its developmental processes (gliogenesis, neuronal differentiation, migration, synaptogenesis, etc) occur with great intensity during the suckling period in the rat ${ }^{4}$. The brain is more vulnerable to several types of the aggressions in that phase $^{4}$. Thus, nutritional insults can cause irrevers-

Estudo realizado no Departamento de Nutrição, Universidade Federal de Pernambuco (UFPE), Recife, PE, Brasil; ${ }^{1}$ Doutoranda em Nutrição da UFPE, Professora assistente do Departamento de Ciências da Nutrição, Universidade Federal da Bahia; ${ }^{2}$ Mestrando em Nutrição da UFPE; ${ }^{3}$ Doutor em Psiquiatria da Universidade Estadual de Campinas, Professor Adjunto do Departamento de Neuropsiquiatria, UFPE; ${ }^{4}$ Doutor em Fisiologia da Universidade de São Paulo (USP - Ribeirão Preto), Professor Adjunto do Departamento de Nutrição, UFPE; ${ }^{5}$ Doutora em Farmacologia da Universidade Federal do Ceará, Professora Adjunta do Departamento de Medicina Tropical, UFPE; ${ }^{6}$ Doutor em Farmacologia Experimental e Clínica da Universidade de Paris VI, Professor Adjunto do Departamento de Nutrição, UFPE. CAPES, CNPq, UFPE and UFBA supported this investigation.

Received 12 December 2000, received in final form 2 March 2001. Accepted 12 March 2001.

Dr. Raul Manhães de Castro - Departamento de Nutrição, UFPE, Cidade Universitária - 50670-901 Recife PE - Brasil. FAX 812718473. E-mail: rcastro@nutricao.ufpe.br 
ible alterations ${ }^{5}$. This period is called "brain growth spurt" 6 . In the man, it begins in the prenatal period (last quarter of gestation) continuing until the first years of life ${ }^{4}$.

The malnutrition during the neonatal period in rats results in major neurochemical alterations including those in the neurotransmitter systems ${ }^{7}$. The effects of nutritional insults on the neurotransmitter systems, in particular the serotoninergic one, deserves special attention. This system participates in a wide variety of the functions of the $\mathrm{CNS}^{8}$. There are several experimental evidences about the effects of malnutrition on the serotoninergic system ${ }^{9-11}$. However, there are few works on the effects of manipulations of this system in undernourished subjects, particularly concerning the behavioral expression ${ }^{12,13}$.

Thus, the present work investigated the effects of the malnutrition during the critical period of brain development and the effects of the treatment with SSRI, on the aggressive behavior in adult rats.

\section{METHOD}

Male Wistar rats maintained at room $\left(23 \pm 1^{\circ} \mathrm{C}\right)$ and on a light (6:00 a.m. to 6:00 p.m.) -dark (6:00 p.m. to
6:00 a.m.) cycle was used. The male offspring of rats were kept with 6 animals. The animals were divided according to the diet employee during suckling: nourished group the rats received the control diet with $23 \%$ of protein (Purina of Brazil Ltd.); and malnourished group- the rats had its mothers submitted to diet with $7.8 \%$ protein ("Regional Basic Diet" - RBD) during suckling. The composition of RDB is shown in Table $1^{14}$. After weaning (24 days after birth), all rats received the control diet ad libitum until the day of the experiment. Body weights were determined on the 1st, 24th, 60th and 120th day. On the 120th day after birth, each group was subdivided according to the paradigm used for drug treatment: acute - consisting a single i.p. injection $(1 \mathrm{ml} / \mathrm{kg})$ of saline $(0,9 \% \mathrm{NaCl}$ solution) or citalopram (20 mg/Kg, Lundbeck); chronic - consisting the single injections $(1 \mathrm{ml} / \mathrm{kg} ; 1$ per day during 14 days) of saline or $20 \mathrm{mg} / \mathrm{Kg}$ citalopram. The citalopram was dissolved in saline. It was formed 8 experimental groups, each one containing 20 animals. This way, the groups of adult rats were constituted, into nourished or malnourished ones in the suckling period, acute or chronically treated or not with citalopram. During the 14 days of the chronic treatment the animals were housed individually in cage. The animals were submitted to the aggressiveness tests 1-h after the acute treatment or $24 \mathrm{~h}$ after the chronic treatment. The aggressiveness tests were accomplished

Table 1. Centesimal composition of "Regional Basic Diet" (RBD).

\begin{tabular}{lccccccc}
\hline Ingredients & \multicolumn{7}{c}{ Centesimal composition } \\
\hline & $\mathrm{g} \%$ & Proteins & Carbohydrates & Fats & Ash & Fibers & Kcal \% \\
& & & & & & & \\
\hline Beans a & 18.34 & 3.99 & 10.66 & 0.24 & 0.57 & 1.09 & 60.76 \\
Manioc flour & 64.81 & 0.84 & 48.59 & 0.12 & 0.43 & 5.64 & 198.80 \\
Poor fat-dried and salted & 3.74 & 2.74 & - & 0.06 & 0.06 & - & 11.50 \\
Dried and salted meat fat & 0.35 & - & - & 0.35 & - & - & 3.15 \\
Sweet potato a & 12.76 & 0.30 & 9.99 & 0.03 & 0.20 & 0.48 & 41.43 \\
& 100 & 7.87 & 69.24 & 0.80 & 1.26 & 7.21 & 315.6 \\
\hline
\end{tabular}

a, cooked and dried.

Table 2. Body weight of rats nourished or malnourished during suckling.

\begin{tabular}{lcccc}
\hline Experimental groups & \multicolumn{5}{c}{ Weight $(\mathrm{g})$} \\
\hline & 1st day & 24th day & 60th day & 120th day \\
\hline Nourished groups & $7.53 \pm 0.13$ & $44.35 \pm 1.55$ & $214.9 \pm 6.76$ & $322.75 \pm 9.77$ \\
Malnourished groups & $7.29 \pm 0.12$ & $23.75 \pm 1.07^{*}$ & $173.3 \pm 8.71^{*}$ & $275.25 \pm 5.34^{*}$
\end{tabular}

Rats nourished received the control diet with $23 \%$ protein during the life; and rats malnourished had its mothers submitted to diet with $7.8 \%$ protein during suckling. The animals were weighed on the $1 \mathrm{st}, 24 \mathrm{th}$, 60 th and 120th day. The data are reported as mean \pm SD. ${ }^{*} p<0.01$ compared to the nourished group at the same age (two-tailed Student t-test). 
in an acoustic isolated room, by using a box $(20 \times 20 \times 20$ $\mathrm{cm}$ ) with the floor consisting of parallel metallic bars (interbar distance: $1.3 \mathrm{~cm}$ ), connected to an electric scrambled current source. The test consisted of placing a pair of rats of the same group (matched by weight) in the box, where they received a session of stimuli to induce aggressive responses. Each stimulus (an electric foot-shock) was represented by a $1.6 \mathrm{~mA}$ - $2 \mathrm{~s}$ current pulse. Each session lasted 20 min and was composed by 5 stimuli separated by a 4min interval. During the first $3 \mathrm{~min}$ of this interval, the duration of the aggressive response was quantified by using a digital chronometer. So the total time for obser- vation of aggressive behavior was $900 \mathrm{~s}$. The annotations and the verification of the equipment were preceded in the last minute of each interval. The aggressive response was defined as the presentation of, at least, one of the two following behaviors: a) the animals stayed lifted up on the hind paws, facing one to the other, in a threatening attitude but without direct contact, or b) they maintained evident physical contact (besides being scratched, exhibition of the teeth and emission of characteristic vocalization). The data were compared by the two-tailed Student t-test (body weight) or by the Mann-Whitney U-test (aggressiveness) with the level of significance set at $\mathrm{P} \leq 0.05$.

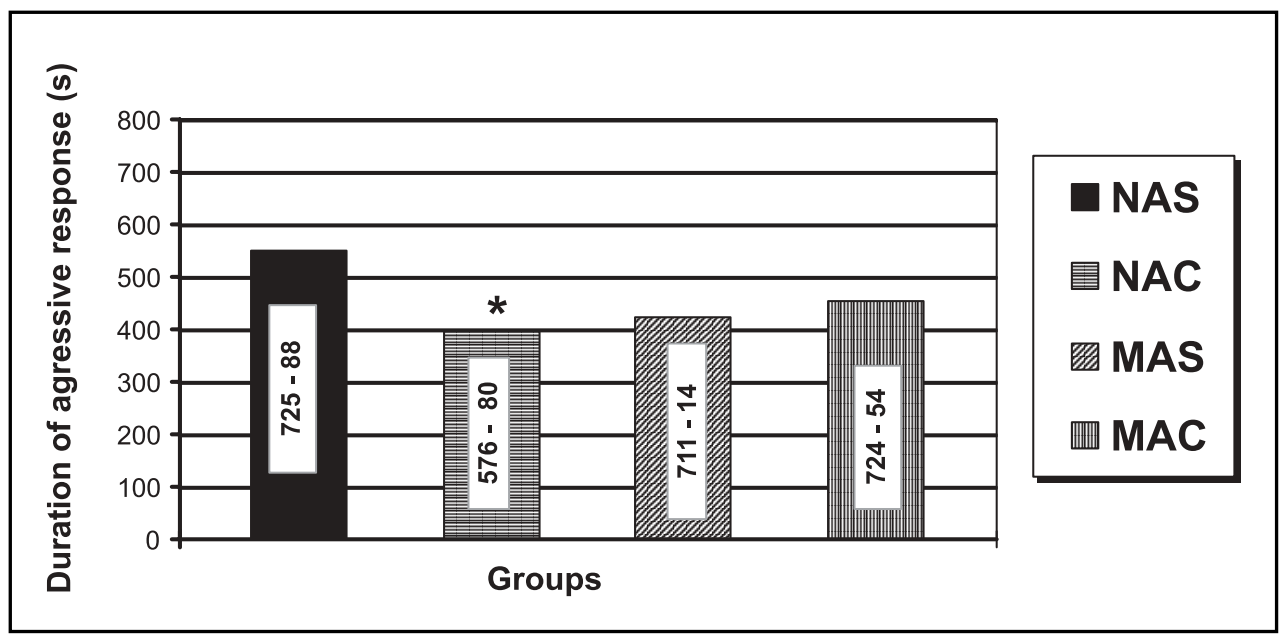

Fig 1. Aggressive responses of rats nourished or malnourished during sucking period, submitted or not to acute treatment with citalopram. The groups nourished acute saline (NAS), malnourished acute saline (MAS) nourished acute citalopram (NAC), malnourished acute citalopram (MAC) were obtained. For each group (20 rats/group), the data are reported as median of time of aggression in seconds, with a range reported inside the columns. ${ }^{*} P<0.05$ compared to saline-treated nourished animals (Mann Whitney two-tailed U-test).

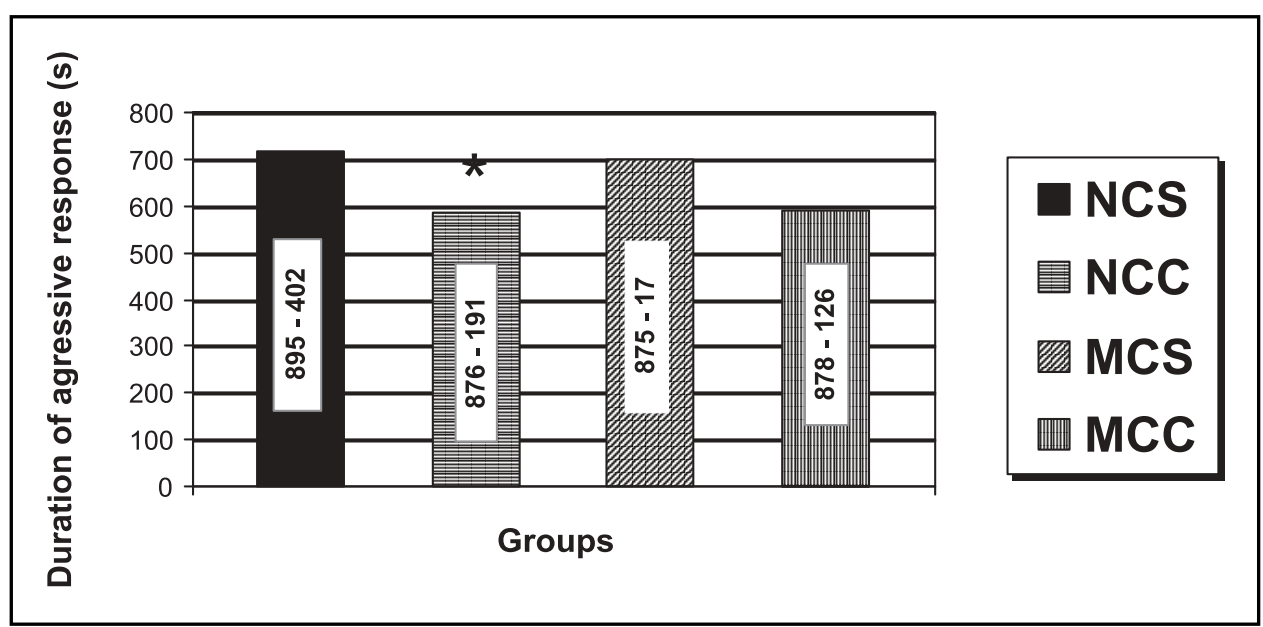

Fig 2. Aggressive responses of rats nourished or malnourished during sucking period, submitted or not to chronic treatment with citalopram. The groups nourished chronic saline (NCS), malnourished chronic saline (MCS) nourished chronic citalopram (NCC), malnourished chronic citalopram (MCC) were obtained. For each group (20 rats/group), the time of aggression this represented in the columns (median), inside the same ones they are the values maximum and minimum. ${ }^{*} P<0,05$ compared to salinetreated nourished animals (Mann - Whitney two-tailed U-test). 


\section{RESULTS}

Compared to the nourished (Table 2), malnourished rats showed a reduction in body weight on the 24th, 60th and 120th day. The acute or chronic treatment with citalopram reduced the aggressive responses in nourished group but not in malnourished one (Figs 1 and 2). The high values of the time of aggressiveness in the animals submitted to the chronic treatment can be due to the largest time of isolation in the cages.

\section{DISCUSSION}

The present study showed that malnutrition during the critical period of brain development impaired the weight evolution of the rats. This effect can be a consequence of the protein deficiency that was imposed the mothers during the suckling period. In this phase, the protein deficiency causes alterations in the quality of the maternal milk ${ }^{15,16}$ that induces damage of the growth of the body in several species of mammals ${ }^{4}$. The treatment with citalopram reduced the intraspecific aggressive response in the nourished rats. This anti-aggressiveness effect of the selective serotonin reuptake inhibitor (SSRI) may be a consequence of an increase in the serotoninergic transmission. The SSRI increase the availability of 5$\mathrm{HT}$ in the synapse and, consequently, the action of this monoamine ${ }^{2}$. However, the malnutrition during brain growth spurt blocked the effect of the SSRI on aggressive behavior in adult rats.

The reduction of aggressiveness after treatment with SSRI found in the present work agrees with previous studies accomplished in humans ${ }^{17}$ and in animals ${ }^{2,18}$. The serotonin has an important role on the emotional processes ${ }^{19}$. Serotoninergic projections innervate cerebral areas that participate in the control of the aggressive behavior ${ }^{19}$. The reduction of the serotoninergic activity seems to increase the aggressiveness ${ }^{20}$. In contrast, the SSRI treatment increasing the synaptic availability of the 5-HT diminishes the aggressive behavior ${ }^{8,21}$. The reduction of the aggressiveness after the treatment with SSRI may be the consequence of the action of the serotonin on the postsynaptic receptors ${ }^{20,22,23}$.

In the present study, the neonatal malnutrition interfered in the effect of the SSRI on the intraspecific aggressiveness in the adult rats. This alteration could be related to the nutritional insult during the neonatal phase. The malnutrition during the neonatal period results in major neurochemical consequences, including those in the neurotransmitter systems ${ }^{7}$. In rats, the first serotoninergic neurons ap- pear between the $12^{\circ}$ and the $14^{\circ}$ day of gestation ${ }^{24}$, but the final density and definitive location of terminals, it is established during the postnatal maturation of the central nervous system ${ }^{25}$. Thus, the malnutrition imposed early in life could cause alterations in the serotonin neurotransmission system, reflecting on its functional responses to drugs. Some drugs which act in the central nervous system has its effects diminished in the malnourished animals ${ }^{12,13,26}$. This suggests a sequel of malnutrition on the serotoninergic system.

In conclusion, the malnutrition during the critical period of brain development renders adult rats resistant to the effect of the SSRI on the aggressive response. The nutritional insult appears to have an enduring effect upon the functioning of the serotoninergic system. Though, it is not still clear which components of the serotoninergic system are altered in a persistent way by the nutritional aggression.

Acknowledgements - The authors thank Lúcia Maria Pires Ferreira for her superb and timely assistance.

\section{REFERENCES}

1. Manhães-de-Castro R, Barreto Medeiros JM, Deiró TCBJ, Mendes da Silva C, Freitas Silva SR, Souza SL. Neonatal treatment with selective serotonin reuptake inhibitor reduces intraspecific aggression in rats. Neurobiologia 1998;61:61-69.

2. Sanchez C, Meier E. Behavioral profiles of SSRIs in animal models of depression, anxiety and aggression. Psychopharmacology 1997;129:197-205.

3. Hyttel J. Effect of a specific 5-HT uptake inhibitor, citalopram (Lu 10171), on 3H-5-HT uptake in rat brain synaptosomes in vitro. Psychopharmacology 1978;60:13-18.

4. Morgane PJ, Miller M, Kemper T, et al. The effects of protein malnutrition on the developing central nervous system in the rat. Neurosci Biobehav Rev 1978;2:137-230.

5. Morgane PJ, Austin-la France RJ, Bronzino J, Tonkiss J, Galler JR. Malnutrition and developing central nervous system. In Isaacson RL, Jensen KF (eds). The vulnerable brain and environmental risks. New York: Plenum Press 1992;1:2-42.

6. Dobbing J. Vulnerable periods in developing brain. In Davison AN, Dobbing J (eds). Applied neurochemistry. Oxford: Blackwell 1968:287316.

7. Winick M, Brasel JA, Rosso P. Nutrition and cell growth. In Winick M (ed). Nutrition and development. London: John Wiley \& Sons 1972:49-98.

8. Chopin P, Moret C, Briley M. Neuropharmacology of 5-hydroxytryptamine $_{1 \mathrm{~B} / 1 \mathrm{D}}$ receptor ligands. Pharmacol Therap 1994;62:385-405.

9. Stern WC, Miller M, Forbes WB, Morgane PJ, Resnick O. Ontogeny of the levels of biogenic amines in various parts of the brain and in peripheral tissue in normal and protein malnourished rats. Exper Neurol 1975;49:314-326.

10. Wiggins RC, Fuller G, Enna SJ. Undernutrition and the development of brain neurotransmitter systems. Undernutr Brain Develop 1984;35:2085-2094.

11. Chen JC, Tonkiss J, Galler J, Volicer L. Prenatal protein malnutrition in rats enhances serotonin release from hippocampus. J Nutr 1992;122: 2138-2143.

12. Hall RD, Leahi JP, Robertson WM. Hyposensitivity to serotoninergic stimulation in protein malnourished rats. Physiol Behav 1983;31:187-195.

13. Almeida SS, Tonkiss J, Galler JR. Malnutrition and reactivity to drugs acting in the central nervous system. Neurosci Biobehav Rev 1996;20:389-402.

14. Teodósio NR, Lago ES, Romani SAM, Guedes RCA. A regional basic diet from Northeast Brazil as a dietary model of experimental malnutrition. Arch Latinoamer Nutr 1990;40:533-547. 
15. Marín MC, Thomás ME, Serres C, Mercuri O. Protein-energy malnutrition during gestation and lactation in rats affects growth rate brain development and essential fatty acid metabolism. J Nutr 1995; 125: 10711024.

16. Sturman JA, Devine E, Resnick O, Morgane PJ. Maternal protein malnutrition in the rat: effect on protein and two enzymes in the milk. Nutr Res 1986;6:437-442.

17. Coccaro EF, Kavoussi RJ. Fluoxetine and impulsive aggressive behavior in personality-disordered subjects. Arch Gen Psychiatry 1997;54: 1081-1088

18. Sánchez C, Hyttel J. Isolation-induced aggression in mice: effects of 5hydroxytryptamine uptake inhibitors and involvement of postsynaptic 5-HT $\mathrm{HA}_{1 \mathrm{~A}}$ receptors. Eur J Pharmacol 1994;264:241-247.

19. Olivier B, Mos J, Oorschot RV, Hen R. Serotonin receptors and animal models of aggressive behavior. Pharmacopsychiatry 1995;28(suppl 2):80-90.

20. Kyes GB. Aggression and brain serotoninergic responsivity: response to slides in male macaques. Physiol Behav 1993;2:205-208.
21. Fuller RW. Pharmacology of central serotonin neurons. Ann Rev Pharmacol Toxicol 1980;20:111-127.

22. Applegate CD. 5,7-Dihydroxytryptamine-induced mouse killing and behavioral reversal with ventricular administration of serotonin in rats. Behav Neural Biol 1980;30:178-190.

23. Eichelman BS. Neurochemical and psychopharmacologic aspects of aggressive behavior. Ann Rev Med 1990;41:149-158.

24. Lauder JM, Bloom FE. Ontogeny of monoamine neurons in locus coeruleous, raphe nuclei and substantia nigra of the rats 1, Cell differentiation. J Comp Neurol 1974;155:469-481.

25. Lidov HGW, Molliver ME. An immunohistochemical study of serotonin neuron development in the rat: ascending pathways and terminal fields. Brain Res Bull 1982;8:389-416.

26. Rotta FT, Mello CF, Rocha JBT, Souza DOG. Early undernutrition blocks the effect of naltrexone on rat exploratory behavior. Braz J Med Biol Res 1988;2:305-312. 